\title{
APLIKASI PUPUK ORGANIK CAIR LAMTORO PADA PERTUMBUHAN DAN HASIL TANAMAN TOMAT
}

\section{THE APPLICATION OF LAMTORO ORGANIC LIQUID FERTILIZER ON TOMATO'S GROWTH AND YIELD}

\author{
Tiara Septirosya*, Ratih Hartono Putri, Tahrir Aulawi \\ Universitas Islam Negeri Sultan Syarif Kasim Riau, Fakultas Pertanian dan Peternakan, \\ H.R Soebrantas KM 15.5, Pekanbaru, Riau 28293 \\ *Korespondensi: tiaraseptirosya@rocketmail.com
}

\begin{abstract}
ABSTRAK
Tomat merupakan salah satu tanaman sayuran penting di Indonesia. Penggunaan pupuk organik cair lamtoro dapat menjadi alternatif dalam menekan penggunaan pupuk anorganik dan memperbaiki kondisi lingkungan. Penelitian ini bertujuan untuk mendapatkan konsentrasi pupuk organik cair lamtoro dan interval waktu aplikasi terbaik untuk pertumbuhan dan hasil tanaman tomat. Penelitian telah dilaksanakan di lahan percobaan dan Laboratorium Agronomi, Fakultas Pertanian dan Peternakan, UIN Sultan Syarif Kasim Riau. Percobaan menggunakan Rancangan Acak Lengkap (RAL) dengan dua faktor, yakni konsentrasi pupuk organik cair lamtoro $(0,10,20,30 \%)$ dan interval waktu aplikasi $(3,6$ dan 9 hari). Hasil penelitian menunjukan bahwa pupuk organik cair lamtoro dengan konsentrasi $10 \%$ efisien untuk meningkatkan tinggi tanaman, diameter batang dan jumlah buah per tanaman. Interval 9 hari memberikan hasil terbaik terhadap parameter tinggi tanaman, jumlah daun dan diameter batang. Tidak terdapat interaksi antara perlakuan konsentarsi dengan waktu aplikasi pupuk organik cair daun lamtoro.
\end{abstract}

Kata kunci: konsentrasi, lingkungan, organik, pupuk, sayur

\begin{abstract}
Tomato is one of the important vegetable in Indonesia. Aplication of Lamtoro organic liquid fertilizer on tomato can suppress the use of inorganic fertilizers and improve the environment. The purpose of research is determine the best concentration and interval time and alse the interaction of concentration and interval time of liquid leaves of lamtoro organic fertilizer. This research was conducted on April to July 2018 at experimental field and Agronomy Laboratory, Faculty of Agriculture and Animal Science, State Islamic University of Sultan Syarif Kasim Riau. Randomized Completely Design (RCD) was applied on this research with two factors. First factor was concentration of Lamtoro organic liquid fertilizer $(0,10,20,30 \%)$ and the second factor was interval of aplication $(3,6$ and 9 days). The results showed that $10 \%$ Lamtoro organic liquid fertilizer was the most efficient treatment to increase plant height, stem diameter and number of fruits of plant. Interval time 9 day gave the best results to increase plant height, number of leave and diameter of stem. There was no interaction between concentration and interval time of Lamtoro liquid organic fertilizer on the growth and yield tomato plants.
\end{abstract}

Keywords: concentration, environment, fertilizer, organic, vegetable

\section{PENDAHULUAN}

Tanaman tomat (Lycopersicum esculentum Mill.) merupakan salah satu jenis sayuran penting di Indonesia. Buahnya merupakan sumber vitamin dan mineral. Penggunaannya lebih luas karena selain dikonsumsi sebagai tomat segar dan untuk bumbu masakan, juga dapat diolah lebih lanjut sebagai bahan baku industri makanan seperti sari buah dan saus tomat (PPPH, 2009).

Tomat berada diurutan kelima produksi tanaman sayuran di Indonesia yang produksinya berfluktuasi setiap tahun. 
Pada 2013 produksinya mencapai 992.780 ton, pada tahun 2014 mengalami penurunan sehingga produksinya menjadi 915.987 ton, di tahun 2015 produksinya hanya mencapai 877.792 ton. Sedangkan konsumsi rumah tangga per kapita, tomat mengalami peningkatan di Indonesia dari 4.171 ons pada tahun 2015 menjadi 4.432 ons pada tahun 2016 (Dirjen Hortikultura, 2016).

Pertumbuhan tomat yang optimal akan ditunjang dengan adanya unsur hara yang cukup. Unsur hara yang dibutuhkan tomat diantaranya N, P, K, Ca dan Mg. Salah satu usaha yang dilakukan untuk peningkatan kualitas dan kuantitas tomat adalah penambahan pupuk organik dalam tanah (Saragih, 2008). Pupuk organik merupakan pupuk yang berasal dari sisa tanaman dan hewan yang sudah mengalami perombakan dan mampu meningkatkan kesuburan kimiawi tanah, meningkatkan kesuburan biologi tanah, dan mempengaruhi sifat fisik tanah yaitu merangsang granulasi dan meningkatkan suplai serta ketersediaan unsur hara seperti N, P, dan K (Sulastri, 2017).

Pupuk organik dapat berbentuk padat maupun cair. Pupuk organik cair adalah pupuk yang dapat memberikan hara sesuai dengan kebutuhan tanaman karena bentuknya yang cair, jika terjadi kelebihan kapasitas pupuk pada tanah, dengan sendirinya tanaman akan mudah mengatur penyerapan komposisi pupuk yang dibutuhkan (Masluki dkk, 2015). Salah satu pupuk organik cair adalah pupuk organik cair daun lamtoro.

Daun lamtoro berpotensi sebagai pupuk yang berpengaruh baik terhadap pertumbuhan dan perkembangan tanaman (Pratiwi, 2009). Lamtoro pada konsentrasi yang sesuai dapat meningkatkan pertumbuhan dan hasil tanaman. Menurut Ratrinia et al. (2014) menyatakan bahwa unsur hara yang terkandung pada daun lamtoro ialah hara esensial yang dibutuhkan untuk pertumbuhan dan perkembangan. Kurniati dkk. (2017) menambahkan bahwa semakin tinggi konsentrasi kandungan daun lamtoro maka semakin tinggi kadar $\mathrm{C}$ pada pupuk cair.

Penggunaan daun lamtoro sebagai pupuk organik cair telah diteliti sebelumnya pada tanaman pakcoy (Roidi, 2016) dan kedelai (Monica, 2015). Belum terdapat penelitian sebelumnya tentang penggunaan daun lamtoro sebagai pupuk organik cair untuk tanaman tomat.

Tujuan penelitian yaitu mengetahui konsentrasi dan interval waktu terbaik serta mengetahui interaksi konsentrasi dan interval waktu pemberian pupuk organik cair daun lamtoro terhadap pertumbuhan dan hasil tanaman tomat.

\section{METODOLOGI}

\section{Tempat dan Waktu}

Penelitian dilaksanakan di Lahan Percobaan dan Laboratorium Agronomi Fakultas Pertanian dan Peternakan Universitas Islam Negeri Sultan Syarif 
Kasim Riau yang terletak di Jalan H.R Soebrantas Km. 15 Panam, Pekanbaru dan analisis kandungan hara dilakukan di Laboratorium Kimia Hasil Perikanan Universitas Riau. Penelitian dilaksanakan pada April sampai Juli 2018.

\section{Bahan dan Alat}

Bahan yang digunakan dalam penelitian ini masing-masing adalah benih tomat Varietas Servo F1, air cucian beras, EM4, air, tanah topsoil, tetes tebu, pupuk kandang ayam, daun lamtoro. Alat yang digunakan adalah polibag kecil ukuran $18 \mathrm{x}$ $25 \mathrm{~cm}$, polibag besar ukuran $40 \times 50 \mathrm{~cm}$, gelas ukur, meteran, timbangan, dan alat budidaya pertanian.

\section{Metode Penelitian}

Penelitian ini merupakan penelitian eksperimen dengan Rancangan Acak Lengkap (RAL) faktorial, yang terdiri atas 2 faktor. Faktor pertama konsentrasi pupuk organik cair daun lamtoro yang terdiri atas 4 taraf perlakuan dan faktor kedua adalah interval waktu pemberian pupuk organik cair daun lamtoro terdiri atas 3 taraf perlakuan. Berdasarkan perlakuan maka terdapat 12 kombinasi dan setiap perlakuan diulang 6 kali sehingga terdapat 72 satuan percobaan. Setiap satuan percobaan terdapat satu tanaman, sehingga jumlah keseluruhan tanaman yaitu 72 tanaman.

Faktor pertama konsentrasi pupuk organik cair daun lamtoro $(\mathrm{K})$ terdiri atas 4 taraf perlakuan yaitu:

$\mathrm{K}_{0}=0 \%$

$\mathrm{K}_{1}=10 \%(100 \mathrm{ml}$ pupuk cair $+900 \mathrm{ml}$ air $)$
$\mathrm{K}_{2}=20 \%$ (200 ml pupuk cair $+800 \mathrm{ml}$ air $)$ $\mathrm{K}_{3}=30 \%$ (300 ml pupuk cair $+700 \mathrm{ml}$ air) Faktor kedua adalah interval waktu pemberian pupuk organik daun lamtoro (I) terdiri atas 3 taraf perlakuan yaitu:

$I_{1}=3$ Hari sekali

$\mathrm{I}_{2}=6$ Hari sekali

$\mathrm{I}_{3}=9$ Hari sekali

\section{Pelaksanaan Penelitian}

Pembuatan pupuk cair daun lamtoro dilakukan dengan cara fermentasi dengan bioaktivator EM-4. Bahan yang digunakan adalah daun lamtoro, air, air cucian beras, tetes tebu dan EM-4 dengan perbandingan $10 \mathrm{~kg}: 20 \ell: 4 \ell: 1 \ell: 1 \ell$ (Monica, 2015). Daun lamtoro dihancurkan dengan cara diblender, kemudian dimasukkan ke dalam wadah fermentasi, tambahkan $4 \ell$ air cucian beras, $1 \ell$ tetes tebu dan $1 \ell$ larutan EM-4. Diaduk sampai rata, lalu difermentasikan selama 21 hari (Nainggolan, 2016). Sebelum diaplikasikan terlebih dahulu dilakukan pengenceran sesuai dengan perlakuan konsentrasi hingga volumenya mencapai $1000 \mathrm{ml}$ dengan cara disaring terlebih dahulu.

Benih tomat disemai hingga berumur satu bulan, saat tanaman sudah memiliki 4-5 helai daun. Bibit tomat ditanam pada polibag dengan jarak antar polibag $60 \times 60 \mathrm{~cm}$.

Pemberian pupuk organik cair daun lamtoro terdiri atas 4 konsentrasi, yaitu $0 \%$, 10\%, 20\% dan 30\%. Sebelum diaplikasikan, pupuk organik cair terlebih dahulu diencerkan hingga volumenya mencapai 
$1000 \mathrm{ml}$ untuk setiap konsentrasi. Aplikasi pupuk dilakukan 7 hari setelah pindah tanam hingga tanaman siap dipanen.

\section{HASIL DAN PEMBAHASAN}

\section{Kandungan Unsur Hara Pupuk Organik}

\section{Cair Daun Lamtoro}

Pada Tabel 1 hasil analisis terlihat bahwa kandungan unsur hara $\mathrm{N}$ lebih tinggi dari pada kandungan $\mathrm{P}$ dan K. Sejalan dengan Palimbungan (2006) yang menyatakan bahwa kandungan $\mathrm{N}$ pada pupuk organik cair daun lamtoro merupakan kandungan yang tertinggi yaitu 3,84 \%, jika dibandingkan dengan kandungan P 0,20\% dan 2,06\% K.

Tabel 1. Analisis Unsur Hara Pupuk Organik Cair Daun Lamtoro

\begin{tabular}{ccc}
\multicolumn{3}{c}{ Cair Daun Lamtoro } \\
\hline \multicolumn{3}{c}{ Kandungan Hara $(\mathrm{g} / 100 \mathrm{ml})$} \\
\hline $\mathrm{N}$ & $\mathrm{P}_{2} \mathrm{O}_{5}$ & $\mathrm{~K}_{2} \mathrm{O}$ \\
\hline 0,1196 & 0,0896 & 0,0023 \\
\hline
\end{tabular}

\section{Tinggi Tanaman}

Tabel 2. Rerata Tinggi Tanaman Tomat

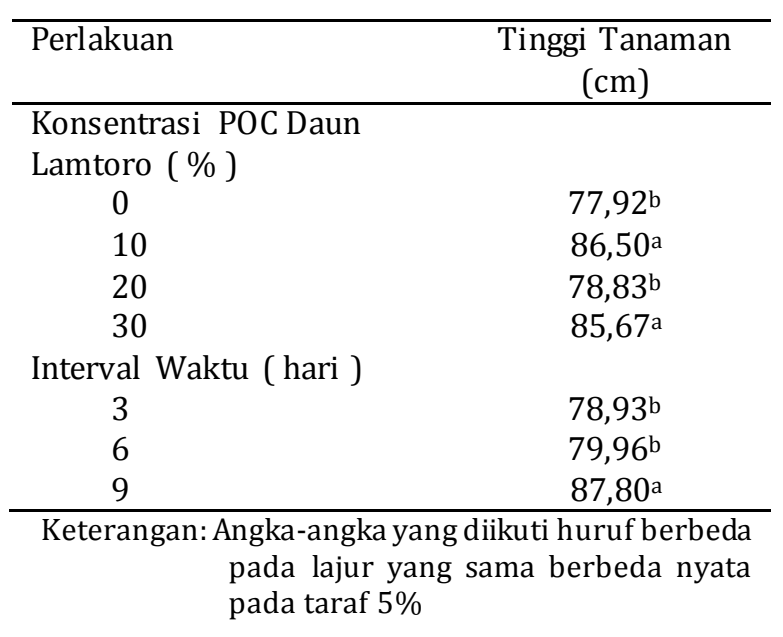

Pemberian konsentrasi pupuk organik cair daun lamtoro konsentrasi $10 \%$ menunjukkan respon terbaik pada parameter tinggi tanaman tomat. Adanya pengaruh konsentrasi pupuk organik cair daun lamtoro dalam meningkatkan pertumbuhan tinggi tanaman diduga karena tingginya kandungan $\mathrm{N}$ pada pupuk organik cair daun lamtoro (1,196 g/100 ml) yang telah mencukupi untuk kebutuhan pertumbuhan vegetatif tanaman tomat. Menurut Jannah et al. (2012) ketersediaan unsur $\mathrm{N}$ yang lebih banyak dimanfaatkan oleh tanaman tomat untuk pertumbuhan vegetatifnya.

\section{Jumlah Daun}

Jumlah daun (Tabel 3) dipengaruhi oleh pemberian pupuk organik cair daun lamtoro pada interval waktu yang berbeda. Interval pemberian 9 hari sekali merupakan waktu pemberian paling efisien untuk meningkatkan jumlah daun pada tanaman tomat. Hal ini diduga karena waktu proses dekomposisi yang optimal menyebabkan laju pelepasan udara berlangsung sehingga ketersediaan hara semakin meningkat.

Tabel 3. Rerata Jumlah Daun Tanaman Tomat

\begin{tabular}{cc}
\hline \multicolumn{1}{c}{ Perlakuan } & $\begin{array}{c}\text { Jumlah Daun } \\
\text { ( helai ) }\end{array}$ \\
\hline $\begin{array}{c}\text { Konsentrasi POC } \\
\text { Lamtoro ( } \%)\end{array}$ & \\
0 & Daun \\
10 & 101,33 \\
20 & 110,89 \\
30 & 106,67 \\
Interval Waktu ( hari ) & 115,39 \\
3 & \\
6 & $102,83^{\mathrm{b}}$ \\
9 & $103,79 \mathrm{~b}$ \\
\end{tabular}

Keterangan: Angka-angka yang diikuti huruf berbeda pada lajur yang sama berbeda nyata pada taraf $5 \%$ 


\section{Diameter Batang}

Tabel 4. Rerata Diameter Batang Tanaman Tomat

\begin{tabular}{lc}
\hline Perlakuan & $\begin{array}{c}\text { Diameter Batang } \\
(\mathrm{cm})\end{array}$ \\
\hline Konsentrasi POC & Daun \\
Lamtoro (\%) & $0,81^{\mathrm{ab}}$ \\
0 & $0,87^{\mathrm{a}}$ \\
10 & $0,78^{\mathrm{b}}$ \\
20 & $0,89^{\mathrm{a}}$ \\
30 & \\
Interval Waktu ( hari ) & $0,79^{\mathrm{b}}$ \\
3 & $0,82^{\mathrm{b}}$ \\
6 & $0,89^{\mathrm{a}}$ \\
\hline
\end{tabular}

Keterangan: Angka-angka yang diikuti huruf berbeda pada lajur yang sama berbeda nyata pada taraf $5 \%$

Pada penelitian ini, diameter batang tanaman tomat dipengaruhi oleh konsentrasi pupuk organik cair daun lamtoro yang diaplikasikan dan interval waktu pemberian (Tabel 4). Pemberian pupuk organik cair daun lamtoro dengan konsentrasi $10 \%$ lebih efisien dalam meningkatkan diameter batang tanaman tomat yaitu sebesar $0,87 \mathrm{~cm}$. Pemberian pupuk organik cair interval 9 hari sekali merupakan interval terbaik dalam meningkatkan diameter batang tanaman tomat yaitu $0,89 \mathrm{~cm}$.

\section{Umur Panen}

Tabel 5. Rerata Umur Panen Tanaman Tomat

\begin{tabular}{lc}
\hline Perlakuan & $\begin{array}{c}\text { Umur Panen } \\
\text { ( hari ) }\end{array}$ \\
\hline Konsentrasi POC Daun & \\
Lamtoro (\%) & \\
0 & 44,00 \\
10 & 45,17 \\
20 & 48,83 \\
30 & 45,72 \\
Interval Waktu ( hari ) & \\
3 & 47,66 \\
6 & 44,83 \\
9 & 45,29 \\
\hline
\end{tabular}

Pada Tabel 5 dapat dilihat bahwa pemberian konsentrasi dan interval waktu pemberian pupuk organik cair daun lamtoro menunjukkan umur panen tanaman tomat yang tidak berbeda nyata. Pada penelitian ini umur panen tanaman tomat lebih cepat dari deskripsi varietas yaitu 62-65 hari. Koesriharti et al., (2012) tanaman yang cepat memasuki fase generatif akan cenderung lebih awal mencapai umur panen. Salah satu indikator dalam memprediksi umur panen yaitu umur berbunga. Umur berbunga yang lambat cenderung memiliki umur panen yang lambat juga.

Interval waktu pemberian pupuk organik cair daun lamtoro terbaik yaitu pada 6 hari sekali yaitu 44,83 hari. Hal ini diduga karena interval waktu pemberian pupuk organik cair daun lamtoro 6 hari sekali yang diberikan dapat mensuplai berbagai unsur hara yang dibutuhkan bagi tanaman untuk proses pertumbuhan khusus mempercepat umur panen tanaman, begitu pula dengan semakin seringnya frekuensi aplikasi pupuk yang diberikan, maka nutrisi tanaman akan semakin tinggi. 


\section{Jumlah Buah per Tanaman}

Tabel 6. Rerata Jumlah Buah Per Tanaman Tomat

\begin{tabular}{lc}
\hline Perlakuan & $\begin{array}{c}\text { Jumlah Buah } \\
\text { (buah) }\end{array}$ \\
\hline
\end{tabular}

Konsentrasi POC Daun

Lamtoro (\%)

\begin{tabular}{ll}
0 & $7,89^{\mathrm{b}}$ \\
10 & $11,06^{\mathrm{ab}}$ \\
20 & $9,06^{\mathrm{ab}}$ \\
30 & $12,72^{\mathrm{a}}$ \\
& \\
3 & 9,71 \\
6 & 9,17 \\
9 & 11,67 \\
\hline
\end{tabular}

Keterangan: Angka-angka yang diikuti huruf berbeda pada lajur yang sama berbeda nyata pada taraf $5 \%$

Pada Tabel 6 dapat dilihat bahwa pemberian konsentrasi pupuk organik cair daun lamtoro memberikan perbedaan terhadap jumlah buah tanaman tomat. Konsentrasi pupuk organik cair daun lamtoro 30\% menghasilkan jumlah buah terbanyak yaitu 12,72 buah, namun tidak berbeda nyata dengan perlakuan konsentrasi 10 dan 20\%. Pada penelitian ini jumlah buah per tanaman tomat belum mencapai deskripsi varietas, karena unsur hara $\mathrm{P}$ dan $\mathrm{K}$ yang terkandung di dalam pupuk organik cair daun lamtoro tergolong rendah.

Interval waktu pemberian pupuk organik cair daun lamtoro tidak berpengaruh terhadap jumlah buah tanaman tomat. Jumlah buah tanaman tomat berkisar 9,17-11,67 buah. Hal ini disebabkan karena kandungan unsur hara $\mathrm{P}$ dan $\mathrm{K}$ pada pupuk organik cair daun lamtoro kurang dari standar kualitas pupuk organik berdasarkan SNI.

\section{Bobot Buah per Buah}

Tabel 7. Rerata Bobot Buah Per Buah Tanaman Tomat

\begin{tabular}{ll}
\hline Perlakuan & $\begin{array}{l}\text { Bobot Buah per } \\
\text { Buah ( g ) }\end{array}$ \\
\hline Konsentrasi POC Daun & \\
Lamtoro (\%) & \\
0 & 29,86 \\
10 & 35,93 \\
20 & 37,58 \\
30 & 32,62 \\
Interval Waktu ( hari ) & \\
3 & 33,97 \\
6 & 32,14 \\
9 & 35,88 \\
\hline
\end{tabular}

Pemberian konsentrasi dan interval waktu pemberian pupuk organik cair daun lamtoro menghasilkan bobot buah per buah tanaman tomat yang tidak berbeda antar perlakuan (Tabel 7). Pada penelitian ini bobot buah per buah belum mencapai deskripsi varietas tomat. Hal ini diduga karena unsur hara $\mathrm{P}$ dan $\mathrm{K}$ yang dikandung oleh pupuk organik cair daun lamtoro belum dapat memenuhi kebutuhan tanaman tomat.

Peningkatan konsentrasi POC daun lamtoro perlu dilakukan untuk dapat menunjang bobot buah tomat. Berdasarkan hasil penelitian Kurniati et al. (2017) menyatakan bahwa semakin tinggi konsentrasi daun lamtoro maka semakin tinggi pula kandungan $\mathrm{P}$ dan $\mathrm{K}$ yang dikandung. 


\section{Diameter Buah}

Tabel 8. Rerata Diameter Buah Tomat

\begin{tabular}{llc}
\hline Perlakuan & $\begin{array}{c}\text { Diameter Buah } \\
(\mathrm{cm})\end{array}$ \\
\hline Konsentrasi POC & Daun & \\
Lamtoro (\%) & & 3,23 \\
0 & 3,64 \\
10 & 3,53 \\
20 & 3,55 \\
30 & \\
Interval Waktu ( hari ) & 3,64 \\
3 & 3,30 \\
6 & 3,53 \\
9 & \\
\hline
\end{tabular}

Pada Tabel 8 terlihat bahwa konsentrasi dan interval waktu pemberian pupuk organik cair daun lamtoro tidak memberikan perbedaan yang nyata terhadap diameter buah. Pada penelitian ini tanaman tomat memiliki ukuran diameter buah yang relatif seragam dan sangat dominan ditentukan oleh faktor dalam tanaman tomat. Lakitan (2011) menyebutkan bahwa ukuran buah lebih dikendalikan oleh faktor genetik (faktor dalam). Faktor genetik sangat dominan dalam mempengaruhi diameter buah tanaman tomat.

Diameter buah tanaman tomat mempunyai hubungan kontribusi dengan bobot buah per tanaman. Semakin besar diameter buah tomat maka akan memberikan bobot buah per tanaman tomat semakin tinggi. Putri et al. (2014) menyebutkan bahwa diameter buah berkorelasi positif terhadap produktivitas. Hal ini berarti semakin besar diameter buah semakin besar pula produktivitasnya.

\section{KESIMPULAN}

Pemberian konsentrasi pupuk organik cair daun lamtoro $10 \%$ lebih efisien dalam meningkatkan tinggi tanaman, diameter batang dan jumlah buah per tanaman. Interval waktu 9 hari pemberian pupuk organik daun lamtoro memberikan hasil terbaik dalam meningkatkan tinggi tanaman, jumlah daun dan diameter batang. Tidak terdapat interaksi perlakuan antara konsentrasi pupuk organik cair daun lamtoro dengan interval pemberian pupuk organik cair daun lamtoro terhadap pertumbuhan dan hasil tanaman tomat.

\section{DAFTAR PUSTAKA}

Direktorat Jenderal Hortikultura. 2016. Statistik konsumsi hortikultura. Http://hortikultura.go.id

Jannah, N., Patah A. \& Muhtar. 2012. Pengaruh pemberian beberapa jenis pupuk kandang dan nutrisi saputra terhadap pertumbuhan dan hasil tomat (Lycopersicum esculentum Mill.) Varietas Permata. Jurnal Ziraa'ah, 35(2):169-179.

Koesriharti, H., Ninuk \& Syamira. 2012. Effect of water management on yield of tomato plant (Lycopersicum esculentum Mill.). Journal of Agriculture and Food Technology, 2(1):16-20.

Kurniati, E., Shirajjudin, A.D., Imani E.S. 2017. Pengaruh penambahan bioenzim dan daun lamtoro ( $L$. Leucocephala) terhadap kandungan unsur hara makro (C, N, P dan $\mathrm{K}$ ) pada pupuk organik cair (POC) lindi (Leachate). Jurnal Sumberdaya Alam dan Lingkungan. 4 (1): 20-26.

Lakitan, B. 2011. Dasar-dasar fisiologi tumbuhan. Rajawali press. Jakarta

Masluki, Naim, M \& Mutmainnah. 2015. Pemanfaatan pupuk organik cair (POC) pada lahan sawah melalui 
sistem mina padi. Prossiding Seminar Nasional. Universitas Cokroaminoto Palopo. Palopo.

Monica, R. 2015. Pengaruh pemberian pupuk cair lamtoro (Leucaena leucocephala L.) terhadap pertumbuhan dan produktivitas tanaman kedelai (Glycine max) var. Grobogan. Skripsi. Program Studi Pendidikan Biologi. Fakultas Keguruan dan Ilmu Pendidikan. Universitas Sanata Dharma. Yogyakarta.

Palimbungan, D., Robert, L., \& Faizal, H. 2006. Pengaruh ekstrak daun lamtoro sebagai pupuk organik cair. Jurnal Agrisisten, 2 (2):2.

[PPPH] Pusat Penelitian dan Pengembangan Hortikultura. 2009. Varietas unggul tomat hibrida dari Balai Penelitian Tanaman Sayuran. Lembang.

Pratiwi, N. R. M. 2009. Pemanfaatan daun lamtoro terhadap pertumbuhan tanaman anggrek tanah (Vanda sp.) pada campuran media pasir dan tanah liat. Skripsi. Program Studi Biologi. Fakultas Keguruan dan Ilmu Pendidikan.Universitas Muhamadiyah Surakarta. Jawa Tengah.

Purnami, W.G. Yuswanti, N. H. \& Astiningsih M. A. 2014. Pengaruh jenis dan frekuensi penyemperotan leri terhadap pertumbuhan bibit anggrek (Phalaenopsis sp) pasca aklimatisasi. Jurnal Agroekoteknologi Tropika, 3(1): 2231.

Putri, R.M., Adiwarman., \& Zuhry, E. 2014. Studi pertumbuhan dan daya hasil empat galur tomat di dataran rendah. Jom Faperta Unri, 1(2):1-9.

Ratrinia, P.W., Maruf, W.F. \& Dewi, E. N.. 2014. Pengaruh penggunaan bioaktivator EM4 dan penambahan daun lamtoro (Leucaena leucophala) terhadap spesifikasi pupuk organik cair rumput laut Eucheuma spinosum. Jurnal Pengolahan dan Bioteknologi Hasil Perikanan, 3(3): 82-87.

Roidi, A.A. 2016. Pengaruh pemberian pupuk organik cair daun lamtoro terhadap pertumbuhan dan produktivitas tanaman sawi pakcoy (Brasicca rapa L.). Skripsi. Program Studi Pendidikan Biologi. Fakultas Keguruan dan Ilmu Pendidikan. Universitas Sanata Darma. Yogyakarta. 